\title{
Education of children and adolescents for the prevention of dog bite injuries (Review)
}

\author{
Duperrex O, Blackhall K, Burri M, Jeannot E
}

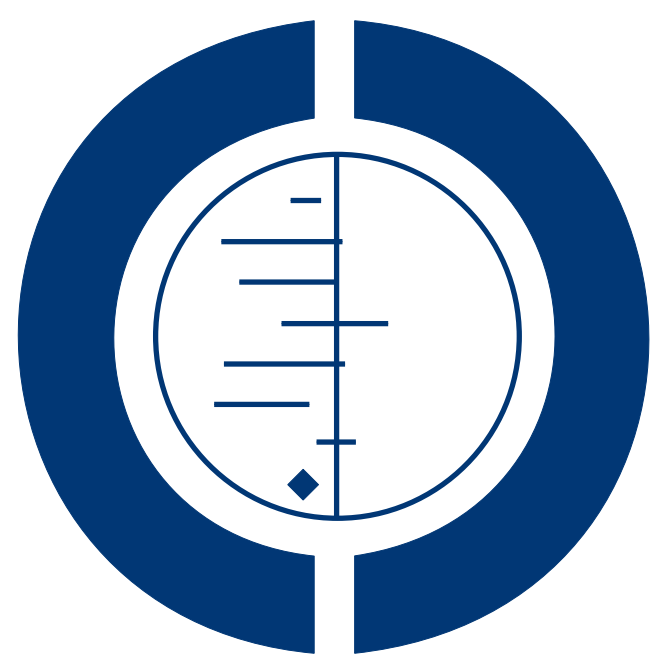

\section{THE COCHRANE COLLABORATION $^{\circledR}$}

This is a reprint of a Cochrane review, prepared and maintained by The Cochrane Collaboration and published in The Cochrane Library 2009, Issue 2

http://www.thecochranelibrary.com

\section{WILEY}


TABLE OF CONTENTS

HEADER . . . . . . . . . . . . . . . . . . . . . . . . . . . . . . . . . . 1

ABSTRACT . . . . . . . . . . . . . . . . . . . . . . . . . . . . . . . . . . . . . . . . . . . . . . .

PLAIN LANGUAGE SUMMARY . . . . . . . . . . . . . . . . . . . . . . . . . . . . . . . . . . . 2

BACKGROUND . . . . . . . . . . . . . . . . . . . . . . . . . . . . . . . . . . . . . . . . .

OBJECTIVES . . . . . . . . . . . . . . . . . . . . . . . . . . . . . . . . . . . . . .

METHODS . . . . . . . . . . . . . . . . . . . . . . . . . . . . . . . . . . . . . . 3

Figure 1. . . . . . . . . . . . . . . . . . . . . . . . . . . . . . . . . . . . . . 5

RESULTS . . . . . . . . . . . . . . . . . . . . . . . . . . . . . . . . . . . . . . . 6

Figure 2. . . . . . . . . . . . . . . . . . . . . . . . . . . . . . . . . . . . . 7

Figure 3. . . . . . . . . . . . . . . . . . . . . . . . . . . . . . . . . . . . . . 8

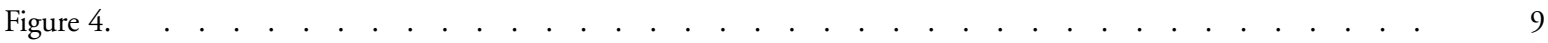

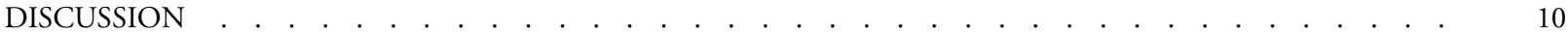

AUTHORS' CONCLUSIONS . . . . . . . . . . . . . . . . . . . . . . . . . . . . . . . . . . . . . .

ACKNOWLEDGEMENTS . . . . . . . . . . . . . . . . . . . . . . . . . . . . . . . . . . . . . . . . 11

REFERENCES . . . . . . . . . . . . . . . . . . . . . . . . . . . . . . . . . . . . . . 11

CHARACTERISTICS OF STUDIES . . . . . . . . . . . . . . . . . . . . . . . . . . . . . . 14

DATA AND ANALYSES . . . . . . . . . . . . . . . . . . . . . . . . . . . . . . . . . . . . . . . . . . . . . .

Analysis 1.1. Comparison 1 Education vs no education, Outcome 1 Inappropriate behaviour (observed). . . . . . 18

APPENDICES . . . . . . . . . . . . . . . . . . . . . . . . . . . . . . . . . . . . . . 18

HISTORY . . . . . . . . . . . . . . . . . . . . . . . . . . . . . . . . . . . . . . . . .

CONTRIBUTIONS OF AUTHORS . . . . . . . . . . . . . . . . . . . . . . . . . . . . . . . . . . . . . . . . .

DECLARATIONS OF INTEREST . . . . . . . . . . . . . . . . . . . . . . . . . . . . . . . . . . . 21

SOURCES OF SUPPORT . . . . . . . . . . . . . . . . . . . . . . . . . . . . . . . . . . . 21

DIFFERENCES BETWEEN PROTOCOL AND REVIEW . . . . . . . . . . . . . . . . . . . . . . 21

INDEX TERMS . . . . . . . . . . . . . . . . . . . . . . . . . . . . . . . . . . . . . 22 


\title{
[Intervention Review] \\ Education of children and adolescents for the prevention of dog bite injuries
}

\author{
Olivier Duperrex ${ }^{1}$, Karen Blackhall ${ }^{2}$, Mafalda Burri $^{1}$, Emilien Jeannot ${ }^{1}$ \\ ${ }^{1}$ Institut de Médecine Sociale et Préventive, Université de Genève, Geneva, Switzerland. ${ }^{2}$ Cochrane Injuries Group, London School of \\ Hygiene \& Tropical Medicine, London, UK \\ Contact address: Olivier Duperrex, Institut de Médecine Sociale et Préventive, Université de Genève, 1, rue Michel-Servet, CH-1211 \\ Genève 4, Geneva, Switzerland. Olivier.Duperrex@unige.ch.
}

Editorial group: Cochrane Injuries Group.

Publication status and date: New, published in Issue 2, 2009.

Review content assessed as up-to-date: 17 July 2008.

Citation: Duperrex O, Blackhall K, Burri M, Jeannot E. Education of children and adolescents for the prevention of dog bite injuries. Cochrane Database of Systematic Reviews 2009, Issue 2. Art. No.: CD004726. DOI: 10.1002/14651858.CD004726.pub2.

Copyright (C) 2009 The Cochrane Collaboration. Published by John Wiley \& Sons, Ltd.

\begin{abstract}
A B S T R A C T
Background

Dog bites can have dramatic consequences for children and adolescents. Educating young people on how to interact with dogs could contribute to reducing dog bite injuries.

\section{Objectives}

To determine the effectiveness of educational interventions that target children and adolescents in reducing dog bite injuries and their consequences.

\section{Search methods}

We searched the following databases: The Cochrane Injuries Group's Specialised Register, CENTRAL (The Cochrane Library Issue 3, 2008), CAB Abstracts, Zetoc, SIGLE, MEDLINE, EMBASE, ERIC, PsycInfo, SPECTR, CINAHL, National Research Register, LILACs, African Healthline, Science Citation Index, Social Science Citation Index, CurrentClinicalTrials.Gov, Centrewatch, Controlledtrials.com, Vetgate and the WHO database. We checked the bibliographies of relevant reviews and trials and also contacted experts in the field. The searches were carried out to 18 July 2008.
\end{abstract}

\section{Selection criteria}

We included randomised controlled trials and controlled before-after studies that evaluated the effectiveness of educational interventions, in populations under 20 years old, for preventing dog bites.

\section{Data collection and analysis}

Two review authors selected eligible studies based on information from the title and abstract. Two review authors decided on the inclusion of eligible trials and extracted data from the trial reports. We contacted authors of eligible studies to obtain more information.

\section{Main results}

Two studies met the inclusion criteria. No study looked at our main outcome: dog bite rates. The included studies were randomised controlled trials conducted in kindergarten and primary schools. Their methodology was of moderate quality. One study showed that the intervention group showed less 'inappropriate behaviour' when observed in the presence of a dog after a 30-minute educational intervention. Another study showed an increase in knowledge and in caution after an information programme.

Education of children and adolescents for the prevention of dog bite injuries (Review)

Copyright $\odot 2009$ The Cochrane Collaboration. Published by John Wiley \& Sons, Ltd. 


\section{Authors' conclusions}

There is no direct evidence that educational programmes can reduce dog bite rates in children and adolescents. Educating children who are less than 10 years old in school settings could improve their knowledge, attitude and behaviour towards dogs. Educating children and adolescents in settings other than schools should also be evaluated. There is a need for high quality studies that measure dog bite rates as an outcome. To date, evidence does not suggest that educating children and adolescents is effective as a unique public health strategy to reduce dog bite injuries and their consequences.

\section{PLAIN LANGUAGE SUMMARY}

\section{The effect of educating children and adolescents on preventing dog bite injuries}

Dog bites can cause significant injuries leading to death or long-lasting disability. The education of children in the school setting could improve their knowledge and attitude towards dogs and encourage safer behaviour around them. The authors of this systematic review examined studies that determined the effectiveness of educational programmes for children and adolescents in preventing dog bite injuries. The educational programmes aimed to change the children and adolescents behaviour towards dogs.

Two studies were included in this review. Both were of moderate methodological quality and evaluated the effectiveness of educating children on preventing dog bite injuries. Both studies involved a 30-minute lesson. One study additionally compared the effect of educating the children's parents through a leaflet. One study videotaped the way children behaved when exposed to an unknown dog, and their behaviour was observed. The main outcome reported in both studies was a change in behaviour.

It is unclear from this review whether educating children can reduce dog bite injuries as dog bite rates were not reported as an outcome in either of the included studies. The effect of educating children and adolescents in settings other than schools has not been evaluated. There is a general lack of evidence about the impact of education to prevent dog bites in children and adolescents, therefore further studies that look at dog bite rates after an intervention are recommended. Education of children and adolescents should not be the only public health strategy to reduce dog bites and their dramatic consequences.

\section{B A C K G R O U N D}

For many years, across the world, children have been bitten by dogs, resulting in acute injury and long-term impairment (Berzon 1974, Chait 1975, Clark 1991, Fritz 1972, Holm 1972, Kale 1977, Schultz 1972). Two reviews of the epidemiology and risk factors of dog bite injuries have estimated rates of dog bites to humans as 160 to 1,800 per 100,000 inhabitants (Overall 2001, Ozanne-Smith 2001).

Expressed as rates per 100,000 inhabitants, dog bites to humans lead to:

- medical treatment - 263 to 300

- emergency department attendance - 73 to 300

- hospitalisation - 2.6 to 7.7

- death - 0.004 to 0.05
Most of these estimates come from high income countries. However, death rates are much higher in low and middle income countries, which may be attributed to the added complication of rabies transmission (Peden 2008). A study of data from Asian countries reported a death rate from animal bites of 2.5 per 100000 children, most of them being from dog bites (Linnan 2007).

Children, particularly boys, are over represented in all studies. Children under five years old have the highest rate of severe wounds. Dog bites to children tend to occur in their own home (66-78\%) and are often on the head or face (51-74\%). Three out of four victims know the dog (Overall 2001, Ozanne-Smith 2001). A study reported that out of 22 children bitten by a dog, 12 showed symptoms of post-traumatic stress disorder seven months after the accident (Peters 2004). Adults, who are mostly bitten on the arms, stay longer in hospital (Overall 2001, Ozanne-Smith 2001).

Other clearly identified risk factors are: male gender, households with dogs, certain breeds, male dogs and leashed dogs. There is a lack of information about environmental determinants, such as

Education of children and adolescents for the prevention of dog bite injuries (Review)

Copyright () 2009 The Cochrane Collaboration. Published by John Wiley \& Sons, Ltd. 
socio-economic factors, housing factors, number of persons living in the home, and neighbourhood issues. Although $29-42 \%$ of attacks are reported as being unprovoked, inappropriate behaviour of the victim is usually considered a risk factor and it is something that can be changed.

One study showed that the risk of people being bitten is greater during weekends than on weekdays (Relative Risk 1.19, 95\% confidence interval 1.10 to 1.29), and higher in summer than winter (Relative Risk 1.24, confidence interval 1.11 to 1.39 ) (Frangakis 2003). "This is consistent with the hypothesis that longer leisure time at these levels of factors does increase the risk of injury from dog bites. Moreover, after controlling for these factors, risk of bite injury was not associated with moon periods" (Frangakis 2003 p.437).

Recommendations for the prevention of dog bite injuries mainly focus on the control of high-risk breeds through legislation, and on the education of professionals (including hospital staff and physicians (Lackmann 1990, Lauer 1982, Moody 2002)) and the public (including dog owners, children and parents (AVMA 2001, Bandow 1996)). Researchers have identified factors in the behaviour of dogs and in the behaviour of children and this is used as a basis to educate children (Riegger 1990, Mathews 1994). The education of children to prevent dog bites is considered to contribute to the reduction of severe injuries to children by teaching children how to modify their behaviour (Sokol 1971, MMWR 2003). As schools are limited in their resources (such as funding and time), questions are often raised as to the effectiveness of interventions in such settings.

\section{Why it is important to do this review}

The aim of this systematic review is to determine the effectiveness of educational interventions that target children and adolescents in reducing dog bites and their consequences. It should help stakeholders with limited budgets to prioritise interventions, by clarifying the potential role of education of children and adolescents amongst the strategies used to reduce the burden of injuries due to dog bites.

\section{O B J E C T IVES}

- To determine the effectiveness of educational programmes for children and adolescents in preventing injuries due to dog bites.

- To determine the effectiveness of educational programmes for children and adolescents in changing their behaviour towards dogs.

\section{METHODS}

\section{Criteria for considering studies for this review}

\section{Types of studies}

- Randomised controlled trials (RCTs), including cluster RCTs.

- Controlled before-after (CBA) trials without randomisation.

The definition of a CBA trial is based on the definition used by the Cochrane Effective Practice and Organisation of Care group and is given below.

\section{RCT}

A study involving at least one test and one control treatment, concurrent enrolment and follow-up of the test- and control-treated groups, and in which the treatments to be administered are selected by a random process, such as the use of a random number table (coin flips are also acceptable). If the author(s) state explicitly (usually by using some variant of the term 'random' to describe the allocation procedure used) that the groups compared in the trial were established by random allocation, then the trial is classified as 'RCT'. Treatment allocations using odd-even numbers, days of the week, or other such pseudo- or quasi-random processes, are designated as quasi-randomised and would therefore be excluded.

\section{Cluster RCT}

Trials in which intact social units, or clusters of individuals, rather than individuals themselves, are randomised to different intervention groups (Donner 2000).

\section{CBA}

A design where there is contemporaneous data collection before and after the intervention and an appropriate control site or activity.

\section{Types of participants}

Children and adolescents (less than 20 years old).

\section{Types of interventions}

Educational programmes aimed at modifying the behaviour of a child or adolescent in the presence of a dog.

- Comparison A: Education vs no education.

- Comparison B: Education with participation of live dog vs education without participation of a live dog. 
Types of outcome measures

\section{Primary outcomes}

- Main: dog bite rates.

- Surrogate: observed behaviour.

\section{Search methods for identification of studies}

Searches were not restricted by language, date or publication status.

\section{Electronic searches}

We searched the following electronic databases:

\section{Health}

- Cochrane Injuries Group Specialised Register (searched 17 July 2008);

- CENTRAL (The Cochrane Library issue 3, 2008);

- MEDLINE (1966 to July (week 1) 2008);

- EMBASE (1980 to July 2008);

- CINAHL (1980 to July 2008)

- National Research Register (to July 2008);

- LILACS - as suggested by Clark 2002 (to July 2008);

- WHO Eastern Mediterranean Literature database (to July 2008);

- African Healthline (1966 to July 2008);

- Current Controlled trials meta register (to July 2008);

- Centerwatch:clinical trials listing service (to July 2008);

\section{Veterinary}

- VetGate: the veterinary pages of Intute (to July 2008);

\section{Educational/Psychological}

- PsycINFO (1970 to July (week 3) 2008);

- ERIC (1966 to July 2008);

- SPECTR (The Campbell Collaboration's trials register) (to July 2008);

\section{General}

- Zetoc (searched 17 July 2008);

- SIGLE (System for information on grey literature in Europe) (to July 2008);

- Web of Science: Science (and Social Science) Citation Index (1970 to July 2008);

- CAB Abstracts (1973 to June 2008).

\section{Searching other resources}

Bibliographies of other relevant reviews and trials were examined for further studies. We also searched relevant safety and veterinary organisations' web sites and contacted experts in the field.

\section{Data collection and analysis}

\section{Selection of studies}

The citations resulting from the search of electronic databases were screened independently by two review authors for potentially relevant reports. The selected articles were obtained in full and the two review authors examined them, independently, in order to determine whether each trial met the pre-defined inclusion criteria.

\section{Data extraction and management}

Two review authors independently extracted data on study participants, intervention type(s), length of follow-up, outcomes evaluated, proportion of dangerous breeds, and prevalence of dog bite rates. Data were also extracted on the method of allocation concealment, blinding of outcomes assessment and loss to follow-up to enable a quality assessment to be made. Information about the legal context, and any change in laws during the study period, was sought by contacting the report authors.

\section{Assessment of risk of bias in included studies}

We used The Cochrane Handbook (Higgins 2008) and Review Manager recommendations for assessing the risk of bias. Authors were contacted, if possible, for clarification of methodological quality. We compared the scores allocated and resolved differences by discussion.

\section{Assessment of heterogeneity}

We did not perform heterogeneity analysis due to the paucity of studies included.

\section{Data synthesis}

\section{Intention-to-treat analysis}

In case of drop-outs, we would have performed an intention-totreat analysis with two assumptions (best-case scenario: none of the drop-outs were bitten; worst-case scenario: all of the drop-outs were bitten) and a sensitivity analysis to test these assumptions. We did not conduct these analyses because no study reported dog bites. 


\section{Dichotomous data}

For dichotomous outcomes, we calculated odds ratios (OR) and risk differences (RD) with their 95\% confidence interval (CI) using Review Manager version 5. We present the number needed to treat (NNT) with 95\% CI for each study. We did not perform a meta-analysis because of the difference in outcome measures and the paucity of studies.

\section{Continuous data}

For direct comparisons between trials that used the same scale to quantify specific outcomes, we would have calculated the weighted mean difference (WMD) with $95 \%$ confidence intervals (CI). We would have calculated the standardised mean differences (with 95\% CI) to compare studies using different scales rating the same effect. We did not perform a meta-analysis because of the difference in outcome measures and the paucity of studies.

\section{Cluster randomisation}

For cluster randomisation trials, we present crude results as well as results with a reduction of subject numbers to an 'effective sample size' with the intracluster correlation coefficient (ICC) provided or calculated from the available data with Acluster 2.1 software (Acluster 2000, Donner 2000, Higgins 2008). If ICC was not available we conducted a sensitivity analysis with estimated ICC of 0.01 and 0.2 (Mytton 2006).

\section{Addressing publication bias}

To detect the possibility of publication bias, data from all identified and included trials were entered into a funnel plot (Figure 1). A test for funnel plot asymmetry was not performed due to a paucity of studies (Egger 1997).

Figure I. Funnel plot of comparison: I Education vs no education, outcome: I.I Inappropriate behaviour (observed).

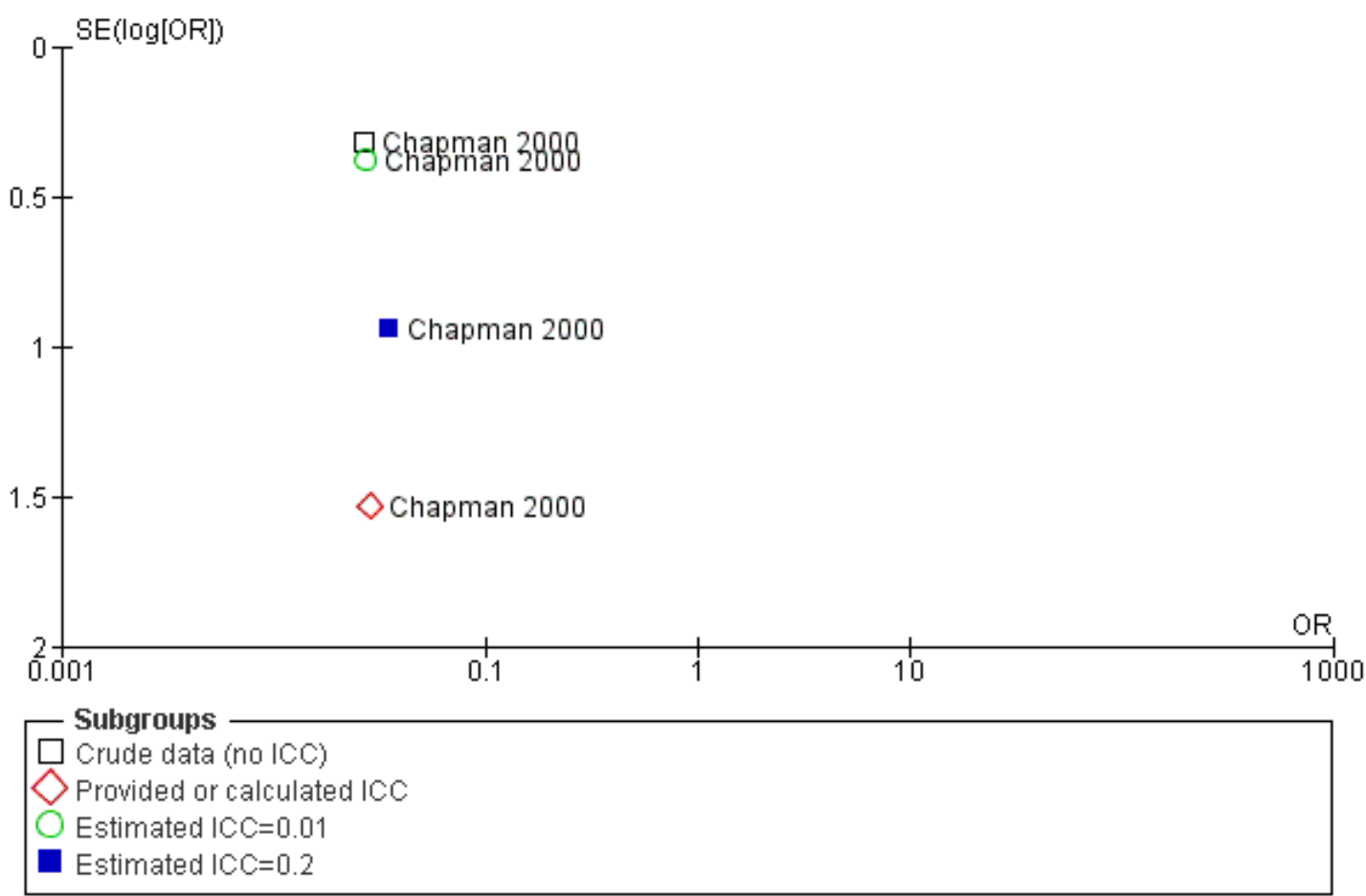

Education of children and adolescents for the prevention of dog bite injuries (Review) 


\section{RES U L T S \\ Description of studies}

See: Characteristics of included studies; Characteristics of excluded studies; Characteristics of ongoing studies.

\section{Results of the search}

The search was carried out to July 2008. From a total of 1598 search results, 20 trial reports were considered eligible of which 2 were included (Chapman 2000, Wilson 2003). One is still under evaluation (De Keuster 2005).

\section{Included studies}

The two included trials are cluster RCTs (Chapman 2000, Wilson 2003). The study awaiting assessment (De Keuster 2005) is a before and after study.

Chapman 2000 conducted a 2-arm cluster randomised trial in 8 primary schools in Sydney, Australia. They enrolled 346 children 7-8 years old (no information about sex). The intervention group had one 30-minute lesson of Prevent-a-Bite by an accredited dog handler (explanation, demonstration and practice: patting the dog + precautionary and protective body posture), whilst the control group had no intervention. They videotaped participants behaviour (children playing in playground unaware of being filmed, with a dog present) 7-10 days after the intervention for 10 minutes and three authors coded a child's behaviour as 'breached' or not.

Wilson 2003 conducted a 4-arm cluster randomised trial in 7 kindergartens in Melbourne, Australia. They enrolled 192 children 4-6 years old. The components of intervention evaluated were an information brochure for parents (Parent-Information (PI)), and a 30-minute story which was read to the children with the aid of puppets and photographs called the Delta DogSafe(TM) program (Child-Program (CP)). The 4 arms were:

1. Parent-Information (PI): information brochure to parents

2. Child-Program (CP): (30-minute story told alongside modelling with photographs and puppets)

3. Parent and Child Information/program (PICP): children in program + information brochure to parents

4. Control (C): no intervention

Wilson 2003 used questionnaires for parents and children before and four weeks after the intervention. Children looked at a series of 10 photographs with a dog in different scenarios (high risk and low risk positions) and were asked to answer "Yes" or "No" to the question "would you pat this dog?". Two indicators were calculated: increased knowledge and increased caution.

See Characteristics of included studies for details.

\section{Excluded studies}

Of the excluded studies, two describe educational programmes without an evaluation of effectiveness (Agan 2000, Monti 1998). Two did not have the relevant study design to be included in this review (Spiegel 2000, Bernardo 2001). One study is a possible RCT but no report could be obtained (Faulconbridge 2001). Klaassen 1996 evaluated the impact of change of legislation with a CBA design. The other excluded studies were either letters or descriptive papers. See Characteristics of excluded studies for details.

\section{Risk of bias in included studies}

The risk of bias is not clearly known for the two included studies (Chapman 2000, Wilson 2003) because of lack of information. Figure 2 and Figure 3 give a visual representation of the review authors' opinion in the risk of bias of each included study. 
Figure 2. Methodological quality graph: review authors' judgements about each methodological quality item presented as percentages across all included studies. Please note: there are only two studies included in this review.

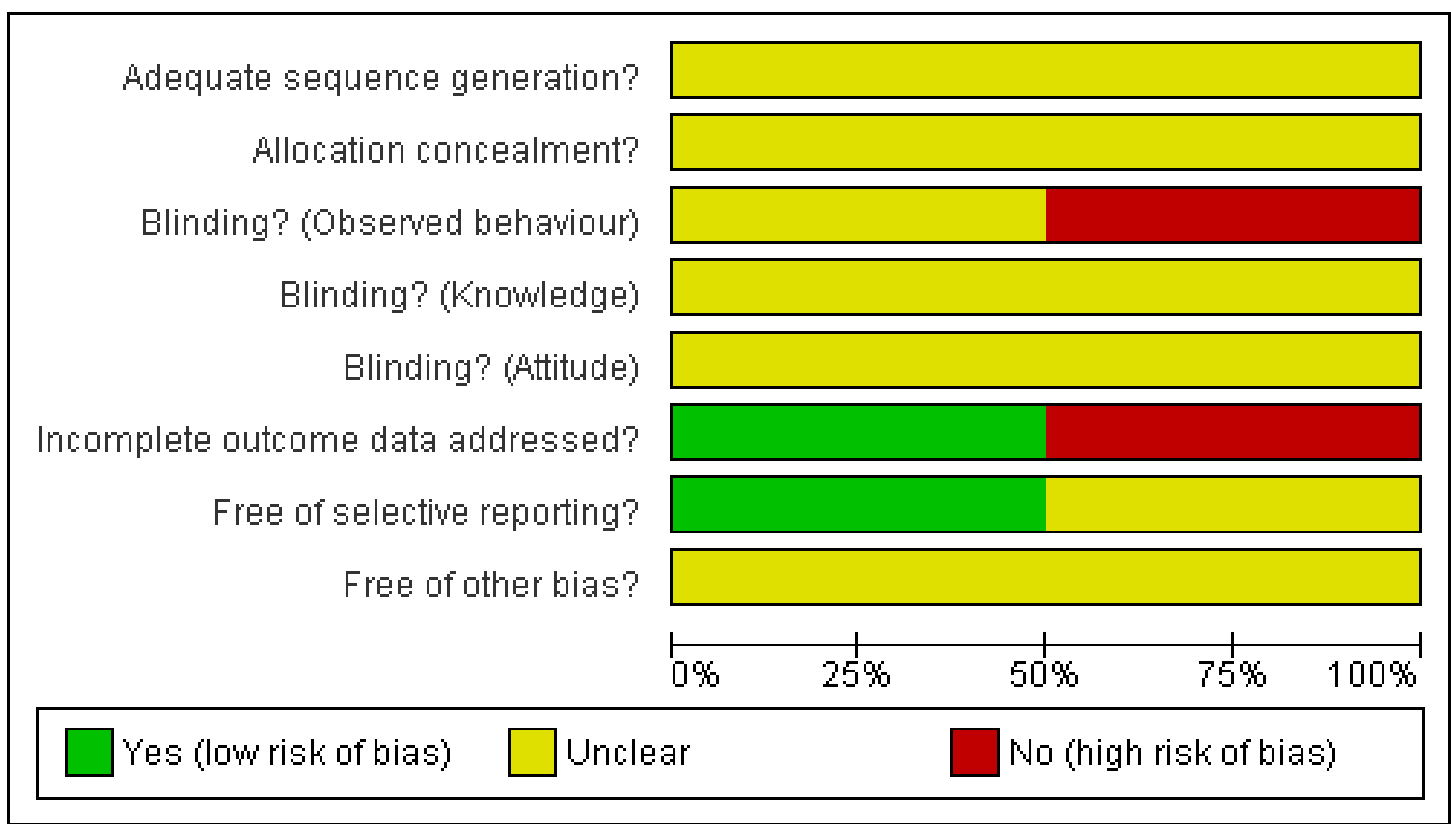


Figure 3. Methodological quality summary: review authors' judgements about each methodological quality item for each included study. Please note: there are only two studies included in this review.

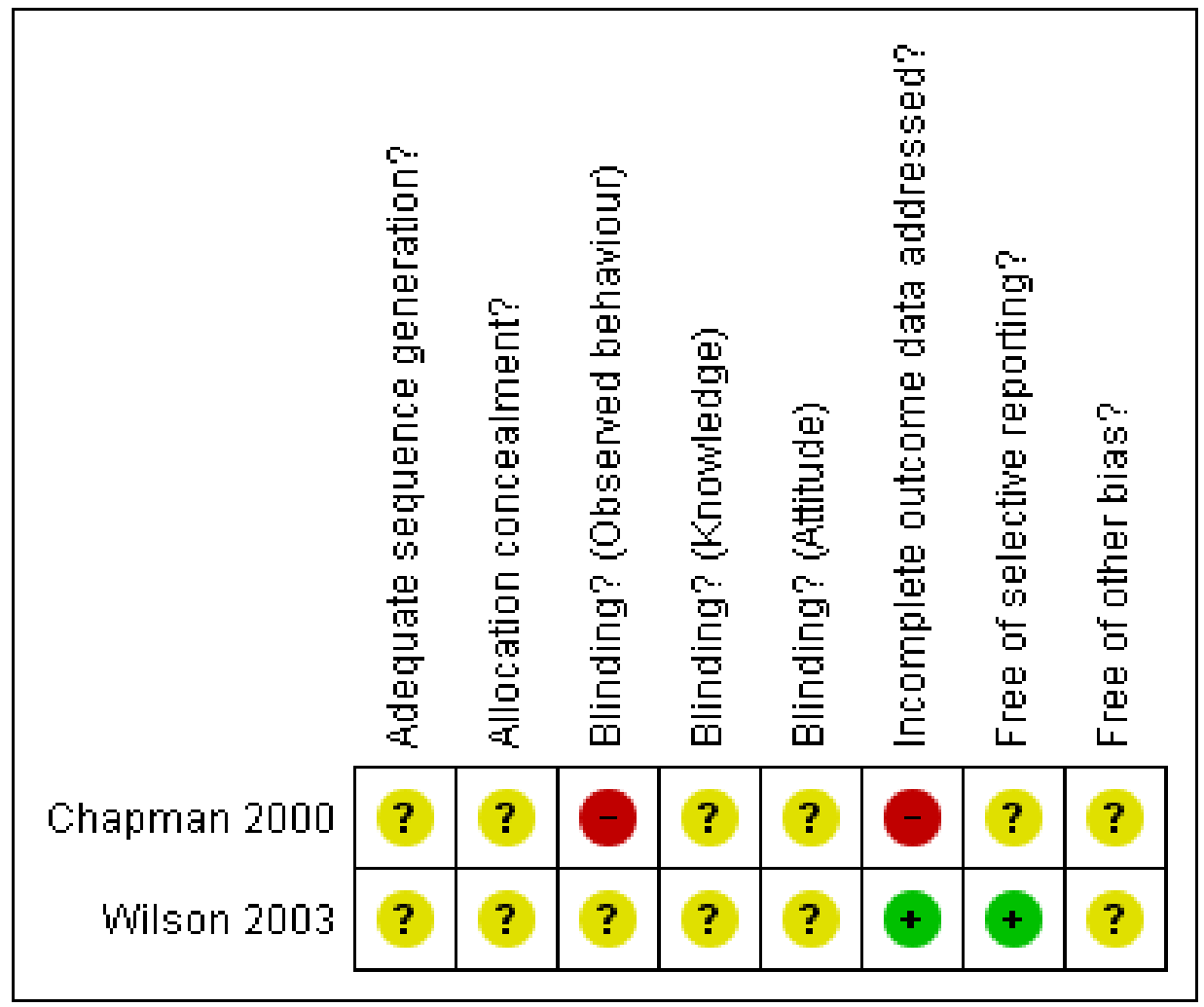

\section{Allocation}

Chapman 2000 randomly selected 8 schools to participate. They were allocated randomly (details not obtained) to intervention group ( $\mathrm{N}=4$ schools) and control group ( $\mathrm{N}=4$ schools). In each school, two classes were selected to participate (details not obtained). The baseline imbalance between the randomised groups cannot be assessed because information was requested but not obtained from authors.

Wilson 2003 randomly (details not obtained) allocated the classes to four arms. The difference in pre-test mean scores were not statistically significant:

1. Parent-Information (PI): (mean 5.14, SD \pm 1.967 )

2. Child-Program (CP): (mean 5.11, $\mathrm{SD} \pm 1.798)$

3. Parent and Child Information/program (PICP): (mean 5.33, $\mathrm{SD} \pm 2.159)$

4. Control (C): (mean 4.20, $\mathrm{SD} \pm 1.813)$

\section{Blinding}

In Chapman 2000 one of the three observers was blind to group allocation. In Wilson 2003, no information was obtained about blinding.

\section{Incomplete outcome data}

Chapman 2000 provides no information about completeness of outcome data. Wilson 2003 indicates that 1 class in the control group dropped out and is therefore not included, leading to a very small control group $(\mathrm{N}=10)$.

\section{Selective reporting}

Selective reporting is possible for Chapman 2000, and is certain for Wilson 2003.

\section{Other potential sources of bias}

- Classification bias could be possible for the assessment of the outcome in both studies, mainly in Chapman 2000.

- Peer influence could have increased the real effect of the intervention in Chapman 2000. A child 'not sure of what to do' might have been directed towards correct behaviour in the 
intervention group more than in the control group because more of his peers would have suggested the correct behaviour.

\section{Effects of interventions}

\section{Chapman 2000}

Fewer children in the intervention group (18/197=9\%) showed inappropriate behaviour (patting the $\mathrm{dog}$ ) than in the control group $(118 / 149=79 \%)$. The crude effect of the educational intervention was:

- odds ratio $0.03 ; 95 \%$ confidence interval 0.01 to 0.05

- risk ratio $0.12 ; 95 \%$ confidence interval 0.07 to 0.18

- risk difference $-0.70 ; 95 \%$ confidence interval -0.78 to 0.62

- number needed to treat $1.43 ; 95 \%$ confidence interval 1.28 to 1.61

The authors did not take into account the cluster effect design in the statistical analysis in the published paper. Data provided in the paper allowed a calculation of intercluster correlation coefficient (ICC) at 0.58915 and a design effect of 25.89147 (see Appendix 2) which was used to compute an effective sample size. The effect of the educational intervention changed to:

- odds ratio $0.03 ; 95 \%$ confidence interval 0.00 to 0.57

- risk ratio $0.15 ; 95 \%$ confidence interval 0.02 to 0.97

- risk difference $-0.70 ; 95 \%$ confidence interval -1.08 to 0.33

- number needed to treat (NNT) 1.43; 95\% confidence interval 0.93 to 3.03 (therefore rounded: NNT 2; 95\% confidence interval 1 to 4 )

As shown in Appendix 2 and commented in Maclennan 2000, the results do not reach statistical significance when using the appropriate methodology for the odds ratio but they remain statistically significant for the other measures. Figure 4 shows the impact on confidence intervals according to the ICC used. Variations on the point values are due to rounding of small numbers. Figure 1 shows the impact on the funnel plot of the ICC. We contacted authors to obtain the detailed initial analysis but had no reply to date.

Figure 4. Forest plot of comparison: I Education vs no education, outcome: I.I Inappropriate behaviour (observed).

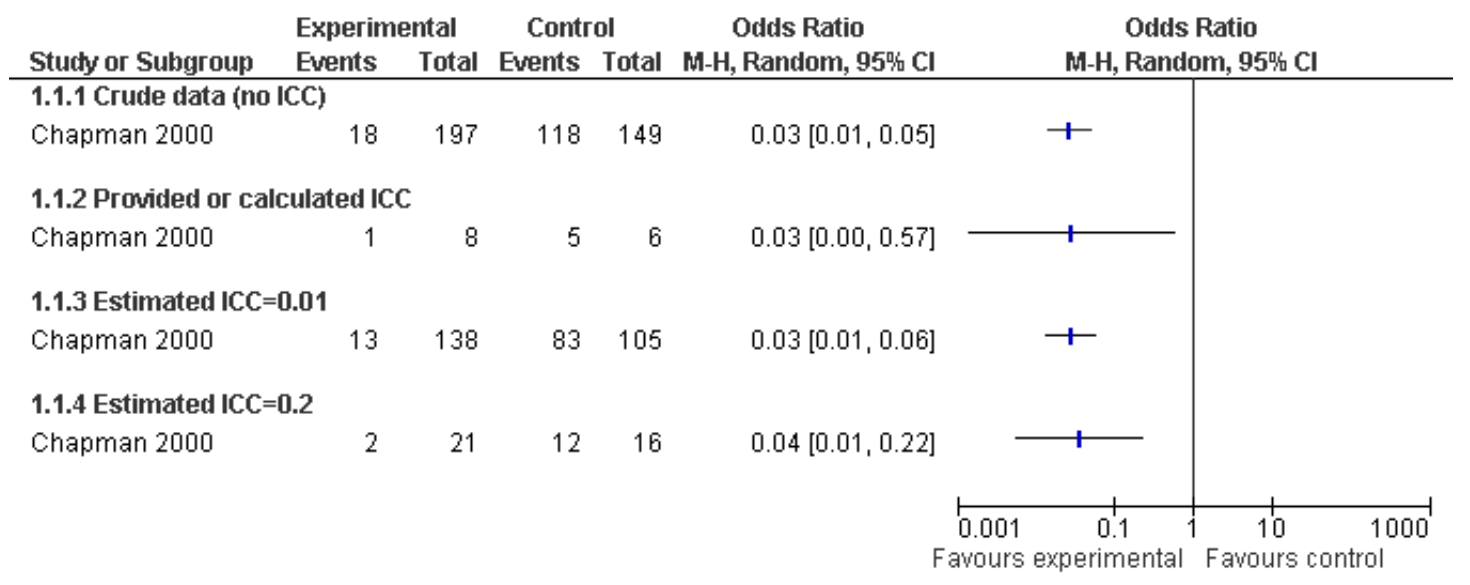

Even with the wider confidence intervals, the half-hour intervention in class reduced the inappropriate behaviour. Between one and four children need to receive the intervention programme in order to gain one child demonstrating the correct behaviour with the dog, when compared to the control group (no intervention).

\section{Wilson 2003}

The authors report that the pre-test mean scores were not signifi- cantly different between the groups:

1. Parent-Information (PI): (mean 5.14, SD \pm 1.967 )

2. Child-Program (CP): (mean 5.11, $\mathrm{SD} \pm 1.798)$

3. Parent and Child Information/program (PICP): (mean $5.33, \mathrm{SD} \pm 2.159)$

4. Control (C): (mean 4.20, $\mathrm{SD} \pm 1.813$ )

The graph in the published paper shows the mean difference for the two indicators and for each group. The authors report in-

Education of children and adolescents for the prevention of dog bite injuries (Review)

Copyright (c) 2009 The Cochrane Collaboration. Published by John Wiley \& Sons, Ltd. 
creased knowledge and increased caution in two groups compared to the control group: alpha $=0.05$ for Child-Program (CP) and alpha $=0.01$ for Parent and Child Information/program (PICP). We requested detailed data from authors but had no reply to date. It is not clear if the cluster design was taken into account in the analysis.

\section{DISCUSSION}

\section{Summary of main results}

Educational interventions for preventing dog bites could change the knowledge, attitude and observed behaviour of children under 10 years old when conducted in school settings according to the results of the two included studies. No study had teenagers as participants. No study focused on dog bite rates as outcome measures.

\section{Overall completeness and applicability of evidence}

There is a lack of well conducted studies on the effectiveness of educational programmes aimed at reducing dog bites. The impressive effect on surrogate outcomes is encouraging but not sufficient to conclude that they can reduce dog bites. The link between the appropriate behaviour of children and the risk of being bitten by a dog is unknown.

Both included studies were conducted in urban settings in Australia. As environment seems to influence the risk of exposure to dog bites (Messam 2008), the cultural and social context could modulate the importance of the effect of the intervention. If the context acts as effect modifier, the applicability to other countries could be limited despite the randomised controlled study design. For instance, the probability of children being in contact with 'wild' dogs is higher in low and middle-income countries, also increasing the risk of being bitten by a rabid dog (Peden 2008). The effect of education could therefore be higher, and more important, than in high income countries.

\section{Quality of the evidence}

The included studies are randomised controlled trials but have several limitations relating to study design or reporting:

- The intervention was short (30 minutes) without the planned 'booster' (Chapman 2000).

- Evaluations were conducted very early after the interventions (7-10 days for Chapman 2000, 4 weeks for Wilson 2003) so lasting effect could not be assessed.
- Lack of information, despite attempts to contact trial report authors, limits the assessment of the quality of the studies and the precision of the effects.

- The comparison is limited because the outcomes were not measured with similar tools.

- Owning a dog, which could be a protective factor (e.g. knowing how a dog reacts, knowing how to handle a dog) or a risk factor (e.g. increased exposure time), was not taken into account for the analysis in the included studies.

\section{Potential biases in the review process}

- Papers published in non-English language databases, and papers indexed in databases not included in the search, and unpublished studies could have been missed. Only one study could be used in Figure 1, showing the impact of the intracluster correlation factor, but not allowing to assess the publication bias.

- At least one possible RCT has been identified but a report could not be obtained (Faulconbridge 2001).

\section{Agreements and disagreements with other studies or reviews}

Insofar as we are aware, this is the first systematic review of effectiveness of educational interventions for preventing dog bite injuries in children and adolescents. Most of the reviews published to date focused on the epidemiology and the treatment of injuries due to dog bites (Chevallier 1999, Whalen 2000, Overall 2001, Ozanne-Smith 2001, MMWR 2003, Agarwal 2004, Marsh 2004, Lang 2005, Lavaud 2005, Ostanello 2005, Abuabara 2006, Schalamon 2006, Morgan 2007) or on their consequences, including psychological effects (Kenardy 2006). Many give general advice on prevention but none has looked at the effectiveness of educating children to avoid dog bites.

\section{AUTHORS' CONCLUSIONS}

\section{Implications for practice}

Short educational programmes to prevent dog bites can be provided in school settings with a probable positive effect in the short term on knowledge, attitude and behaviour of children. The duration of this effect is unknown. No conclusion can be drawn on how best to conduct such programmes. The effectiveness of educating adolescents to prevent dog bites is not known. Public health policies should not rely only on educating children and adolescents as a primary measure to reduce the burden of dog bites in this population. 


\section{Implications for research}

Proper randomised controlled trials should be conducted to evaluate the effectiveness of educational programmes of children and adolescents on dog bite rates. Larger trials should be conducted in order to measure any reduction in dog-bite injuries and to clarify the relationship between children's behaviour and dog bites. Observed behaviour by videotape as reported by Chapman 2000 may be the most suitable way to measure outcomes in this field. The relationship between attitude and observed behaviour should be clarified if attitude is to be used as a surrogate. Focusing on teenagers as future parents could also contribute to reduced dog bite rates in their children. Alternate strategies should be explored, such as educating children in settings other than schools or educating parents of young children. Ownership of a dog should be assessed as a possible confounder in the effect of an educational intervention. Studies should be funded in low and middle-income countries where an educational strategy may contribute to the protection of children and adolescents.

\section{ACKNOWLEDGEMENTS}

We thank the Cochrane Injuries Group for their editorial support.

\section{R E F E R E N C E S}

\section{References to studies included in this review}

\author{
Chapman 2000 \{published data only (unpublished sought but not \\ used)\} \\ * Chapman S, Cornwall J, Righetti J, Sung L. Preventing \\ dog bites in children: randomised controlled trial of an \\ educational intervention. BMJ 2000;320(7248):1512-3. \\ Chapman S, Cornwall J, Righetti J, Sung L. Preventing \\ dog bites in children: randomized controlled trial of an \\ educational intervention. Western Journal of Medicine 2000; \\ $173(4): 233-4$
}

Wilson 2003 \{published data only (unpublished sought but not used)\} Wilson F, Dwyer F, Bennett PC. Prevention of dog bites: Evaluation of a brief educational intervention program for preschool children. Journal of Community Psychology Jan 2003;31(1):75-86.

\section{References to studies excluded from this review}

\section{Agan 2000 \{published data only\}}

Agan EM, Burnette JE, Hendrix CM. Fido! Friend or foe? An activity/coloring book designed to reduce dog bite injuries in children through public education. National Academies of Practice Forum: Issues in Interdisciplinary Care (NAPF). 2000;2(2):151-5.

Avatkova 1979 \{published data only\}

Avatkova II. [Health education of children during summer to prevent poisoning with wild plants, insect stings and animal bites]. [Russian]. Feldsheri Akusherka 1979 Jun;44 (6):43-7.

Bernardo 2001 \{published data only\} Bernardo LM, Gardner MJ, O’Dair J, Cohen B. The PAWS program: Pediatric Animal Awareness and Safety. Journal of Emergency Nursing 2001 Aug;27(4):387-90.

Butcher 2006 \{published data only\} Butcher R. Preventing dog bites. Veterinary Record 2006; 159(15):500.
Chevallier 1999 \{published data only\} Chevallier B, Sznadjer M. [Dog bites in children]. [French]. Archives De Pediatrie 1999 Dec;6(12):1325-30.

Faulconbridge 2001 \{published data only\}

Faulconbridge J. Impact of an information leaflet on the psychological effects experienced by children following accidental injury. Nottingham Primary Care Research Partnership 2001. [: N0171078517 ]

Gilchrist 2001 \{published data only\} Gilchrist, J. Preventing dog bites in children: randomised controlled trial of an educational intervention. Journal of Pediatrics 2001;138(1):143.

Kahn 2003 \{published data only\}

Kahn A, Bauche P, Lamoureux J, Dog Bites Research Team. Child victims of dog bites treated in emergency departments: a prospective survey. European Journal of Pediatrics 2003 Apr;162(4):254-8.

Klaassen 1996 \{published data only\} Klaassen B, Buckley JR, Esmail A. Does the dangerous dogs act protect against animal attacks: a prospective study of mammalian bites in the accident and emergency department. Injury 1996 Mar;27(2):89-91.

Mills 2007 \{published data only\} Mills DS, Shepherd K, Butcher R, De Keuster T. Dog bite prevention. The Veterinary Record 2007;160(12):415.

Monti 1998 \{published data only\}

Monti DJ. Dog bite prevention campaign: nipping a problem in the bud. Journal of the American Veterinary Medical Association 1998 May 1;212(9):1345.

Peak 2002 \{published data only\} Peak K. Safe kids/safe dogs. Journal of Emergency Nursing 2002 Oct;28(5):450-2.

Presutti 2001 \{published data only\} Presutti RJ. Prevention and treatment of dog bites. American Family Physician 2001 Apr 15;63(8):1567-72. 
Riegger 1990 \{published data only\}

Riegger MH, Guntzelman J. Prevention and amelioration of stress and consequences of interaction between children and dogs. Journal of the American Veterinary Medical Association 1990 Jun 1;196(11):1781-5.

Spiegel 2000 \{published data only\}

Spiegel IB. A Pilot Study to Evaluate an Elementary SchoolBased Dog Bite Prevention Program. Anthrozoos 2000;13 (3):164-73.

Taylor 2007 \{published data only\}

Taylor H. Dog bite prevention. The Veterinary Record 2007; 160(12):415.

Whalen 2000 \{published data only\}

Whalen B. Preventing animal bites in children. WMJ. 2000 Dec;99(9):39-42.

\section{References to ongoing studies}

De Keuster 2005 \{published data only\}

Anonymous. Preventing dog bites with the help of the Blue Dog. Veterinary Record 2005;156(16):499.

Butcher R, De Keuster T, Meints K. The Blue Dog projectscientific validation, worldwide response and need for further research. Proceedings of the 11th International Conference on Human-animal Interactions, IAHAIO Conference. Tokyo, 2007:153.

* De Keuster T, De Cock I, Moons C. Dog Bite Prevention: how Blue Dog can help. European Journal of Companion Animal Practice 2005; Vol. 15, issue 2:136-9.

Meints K, De Keuster T. The Blue Dog - do children really get the message?. 2006 World Congress Proceedings. 31st World Small Animal Association Congress, 12th European Congress FECAVA, \& 14th Czech Small Animal Veterinary Association Congress. Prague, Czech Republic: WSAVA, 2006 Oct:822-5.

\section{Additional references}

\section{Abuabara 2006}

Abuabara A. A review of facial injuries due to dog bites.

Medicina Oral, Patologia Oral y Cirugia Bucal 2006 Jul;11

(4):E348-50.

\section{Acluster 2000}

Pinol A, Piaggio G. ACLUSTER - Software for the Design and Analysis of Cluster Randomized Trials. 2.1. Geneva: WHO, 2000.

Agarwal 2004

Agarwal N, Reddajah VP. Epidemiology of dog bites: a community-based study in India. Tropical Doctor 2004 Apr; 34(2):76-8.

\section{AVMA 2001}

American Veterinary Medical Association Task Force on Canine Aggression and Human-Canine Interactions. A community approach to dog bite prevention. Journal American Veterinary Medical Association 2001;218(11): 1732-49.
Bandow 1996

Bandow JH. Will breed-specific legislation reduce dog bites? . Canadian Veterinary Journal 1996;37(8):478-81.

\section{Berzon 1974}

Berzon DR, DeHoff JB. Medical costs and other aspects of dog bites in Baltimore. Public Health Reports 1974;89(4): 377-81.

\section{Chait 1975}

Chait LA, Spitz L. Dogbite injuries in children. South African Medical Journal 1975;49(17):718-20.

\section{Clark 1991}

Clark MA, Sandusky GE, Hawley DA, Pless JE, Fardal PM, Tate LR. Fatal and near-fatal animal bite injuries. Journal of Forensic Science 1991;36(4):1256-61.

\section{Clark 2002}

Clark OA, Castro AA. Searching the Literatura Latino Americana e do Caribe em Ciencias da Saude (LILACS) database improves systematic reviews. International Journal of Epidemiology 2002;31(1):112-4.

\section{Donner 2000}

Donner A, Klar N. Design and analysis of cluster randomization trials in health research. London: Arnold, 2000. [: 0-340-69153-0]

Egger 1997 Egger M, Davey-Smith G, Schneider M, Minder C. Bias in meta-analysis detected by a simple graphical test. $B M J$ 1997;315:629-34.

\section{Frangakis 2003}

Frangakis CE, Petridou E. Modelling risk factors for injuries from dog bites in Greece: a case-only design and analysis. Accident Analysis and Prevention 2003;35(3):435-8.

Fritz 1972

Fritz G. [Treatment of injuries resulting from dog bites]. Wien Klin Wochenschr 1972;84(1):12-6.

Higgins 2008

Higgins JPT, Green S (editors). Cochrane Handbook for Systematic Reviews of Interventions Version 5.0.0 [updated February 2008]. The Cochrane Collaboration, 2008. http:/ /www.cochrane-handbook.org/.

Holm 1972

Holm PC. [Dog bites of the face in Danes and natives of Greenland]. Ugeskr Laeger 1972;134(41):2145-9.

Kale 1977

Kale OO. Epidemiology and treatment of dog bites in Ibadan: a 12-year retrospective study of cases seen at the University College Hospital Ibadan (1962-1973). African Journal of Medical Science 1977;6(3):133-40.

Kenardy 2006

Kenardy JA, Spence SH, Macleod AC. Screening for posttraumatic stress disorder in children after accidental injury. Pediatrics 2006 Sep;118(3):1002-9.

\section{Lackmann 1990}

Lackmann GM, Isselstein G, Tollner U, Draf W. [Facial injuries caused by dog bites in childhood. Clinical staging, 
therapy and prevention]. [German] [Gesichtsverletzungen durch Hundebisse im Kinderalter]. Monatsschrift Fur Kinderheilkunde 1990 Nov;138(11):742-8.

\section{Lang 2005}

Lang ME, Klassen T. Dog bites in Canadian children: A five-year review of severity and emergency department management. CJEM Canadian Journal of Emergency Medical Care 2005;7(5):309-14.

\section{Lauer 1982}

Lauer EA, White WC, Lauer BA. Dog bites. A neglected problem in accident prevention. American Journal of Diseases of Children 1982 Mar;136(3):202-4.

\section{Lavaud 2005}

Lavaud J, Vazquez MP, Bordas VC, Duval C. Domestic animals and accidents in children [Animaux domestiques et accidents chez l'enfant]. Archives de Pediatrie 2005 Feb;12 (2):228-33.

\section{Linnan 2007}

Linnan M, Giersing M, Linnan H, Cox R, Williams MK, Voumard C, Hatfield R. Child mortality and injury in Asia: policy and programme implications. Innocenti Working Paper 2007-07, Special series on child injury No. 4. Florence: UNICEF Innocenti Research Centre, 2007. [: http:// www.unicef-irc.org/publications/pdf/iwp $2007^{\circ}$ 07.pdf]

\section{Maclennan 2000}

Maclennan G, Ramsay C, Grimshaw JM, Campbell MK. Analysis did not account for cluster randomisation. BMJ 2000 December 9;321(7274):1473. [PUBMED: PMC1119180]

\section{Marsh 2004}

Marsh L, Langley J, Gauld R. Dog bite injuries. New Zealand Medical Journal 2004 Sep 10;117(1201):U1043.

\section{Mathews 1994}

Mathews JR, Lattal KA. A behavioral analysis of dog bites to children. Journal of Developmental \& Behavioral Pediatrics $1994 \mathrm{Feb} ; \mathbf{1 5}(1): 44-52$.

\section{Messam 2008}

Messam L, Kass P, Chomel B, Hart L. The human-canine environment: A risk factor for non-play bites?. The Veterinary Journal 2008;177(2):205-15. [DOI: 10.1016/ j.tvjl.2007.08.020]

\section{MMWR 2003}

Gilchrist J, Gotsch K, Annest JL, Ryan G. Nonfatal dog bite-related injuries treated in hospital emergency departments - United States, 2001. Morbidity and Mortality Weekly Report 2003;52(26):605-10.

\section{Moody 2002}

Moody WJ, King R, O'Rourke S. Attitudes of paediatric medical ward staff to a dog visitation programme. Journal of Clinical Nursing 2002 Jul;11(4):537-44.

\section{Morgan 2007}

Morgan M, Palmer J. Dog bites. BMJ (Clinical research ed.) 2007;334(7590):413-7. [PUBMED: 17322257]

\section{Mytton 2006}

Mytton J, DiGuiseppi C, Gough D, Taylor R, Logan S. School-based secondary prevention programmes for preventing violence. Cochrane database of systematic reviews (Online) 2006;3:CD004606. [PUBMED: 16856051]

\section{Ostanello 2005}

Ostanello F, Gherardi A, Caprioli A, La Placa L, Passini A, Prosperi S. Incidence of injuries caused by dogs and cats treated in emergency departments in a major Italian city. Emergency Medicine Journal 2005;22(4):260-2.

\section{Overall 2001}

Overall KL, Love M. Dog bites to humans--demography, epidemiology, injury, and risk. Journal of the American Veterinary Medical Association 2001;218(12):1923-34.

\section{Ozanne-Smith 2001}

Ozanne-Smith J, Ashby K, Stathakis VZ. Dog bite and injury prevention--analysis, critical review, and research agenda. Injury Prevention 2001;7(4):321-6.

\section{Peden 2008}

Peden M, Oyegbite K, Ozanne-Smith J, Hyder Adnan A, Branche C, Rahman AKM F, Rivara F, et al. World report on child injury prevention. Geneva: WHO and UNICEF, 2008. [: ISBN 978924156357 4; : http://www.who.int/ violence injury prevention/child/injury/world report/en/ index.html]

\section{Peters 2004}

Peters V, Sottiaux M, Appelboom J, Kahn A. Post-traumatic stress disorder following dog bites in children. Journal of Pediatrics 2004;144:121-2.

\section{Review Manager}

The Nordic Cochrane Centre. Review Manager. 5.0. Copenhagen: The Cochrane Collaboration, 2008.

\section{Schalamon 2006}

Schalamon J, Ainoedhofer H, Singer G, Petnehazy T, Mayr J, Kiss K, et al.Analysis of dog bites in children who are younger than 17 years. Pediatrics 2006;117(3):e374-9.

\section{Schultz 1972}

Schultz RC, McMaster WC. The treatment of dog bite injuries, especially those of the face. Plastic and Reconstructive Surgery 1972;49(5):494-500.

\section{Schulz 1995}

Schulz KF, Chalmers I, Hayes RJ, Altman DG. Empirical evidence of bias. Dimensions of methodological quality associated with estimates of treatment effects in controlled trials. JAMA 1995;273(5):408-12.

\section{Sokol 1971}

Sokol AB, Houser RG. Dog bites: prevention and treatment. Comments from the surgeon's viewpoint. Clinical Pediatrics 1971 Jun;10(6):336-8.

* Indicates the major publication for the study 


\section{CHARACTERISTICS OF STUDIES}

\section{Characteristics of included studies [ordered by study ID]}

\section{Chapman 2000}

Methods

\begin{tabular}{ll} 
& $\begin{array}{l}8 \text { primary schools randomly selected were allocated by randomisation (no detail available) } \\
\text { to } 2 \text { groups } \\
2 \text { classes were then selected to participate (no detail on how) }\end{array}$ \\
\hline Participants & $\begin{array}{l}346 \text { children }(197 \text { intervention, } 149 \text { control) } 7-8 \text { years old from } 8 \text { primary schools in } \\
\text { metropolitan Sydney ( } 4 \text { intervention, } 4 \text { control) }\end{array}$
\end{tabular}

1. Intervention group: one 30-minute lesson of Prevent-a-Bite by an accredited dog handler (explanation, demonstration and practise: patting the dog + precautionary and protective body posture)

2. Control group: no intervention.

Outcomes

Observed behaviour taped on video: children playing in playground unaware of being filmed, with a dog tethered (with the owner nearby but remaining anonymous so children were unaware of his presence).

Measured 7-10 days after intervention for intervention group

\begin{tabular}{|c|c|c|}
\hline Notes & \multicolumn{2}{|c|}{ Year of evaluation not stated. } \\
\hline \multicolumn{3}{|l|}{ Risk of bias } \\
\hline Item & Authors' judgement & Description \\
\hline Adequate sequence generation? & Unclear & No information provided. \\
\hline Allocation concealment? & Unclear & No information provided. \\
\hline $\begin{array}{l}\text { Blinding? } \\
\text { Observed behaviour }\end{array}$ & No & $\begin{array}{l}\text { Only one in three observers was blind to } \\
\text { group allocation. }\end{array}$ \\
\hline $\begin{array}{l}\text { Blinding? } \\
\text { Knowledge }\end{array}$ & Unclear & Not tested. \\
\hline $\begin{array}{l}\text { Blinding? } \\
\text { Attitude }\end{array}$ & Unclear & Not tested. \\
\hline $\begin{array}{l}\text { Incomplete outcome data addressed? } \\
\text { All outcomes }\end{array}$ & No & $\begin{array}{l}\text { No information provided about loss to fol- } \\
\text { low-up. }\end{array}$ \\
\hline Free of selective reporting? & Unclear & $\begin{array}{l}\text { No information provided to understand if } \\
\text { they looked out for other outcomes or not. } \\
\text { Surprising if they used only videotape to }\end{array}$ \\
\hline
\end{tabular}

Education of children and adolescents for the prevention of dog bite injuries (Review)

Copyright () 2009 The Cochrane Collaboration. Published by John Wiley \& Sons, Ltd. 
Chapman 2000 (Continued)

capture the outcome of the programme

\begin{tabular}{|c|c|}
\hline Free of other bias? & Unclear \\
\hline
\end{tabular}

Wilson 2003

\begin{tabular}{ll}
\hline Methods & RCT, possibly cluster with 4 arms. \\
\hline \multirow{2}{*}{ Participants } & 192 children from 7 kindergartens in Melbourne, Australia \\
& Age range: 4.0 to 5.9 years (mean=4.68, SD=0.40) \\
& Sex: 87 females $(45.5 \%): 104$ males $(54.5 \%)$ \\
& 1. Parent-Information (PI): $\mathrm{n}=48$ \\
2. Child-Program $(\mathrm{CP}): \mathrm{n}=54$ & 3. Parent and Child Information/program (PICP): $\mathrm{n}=65$ \\
& 4. Control $(\mathrm{C}): \mathrm{n}=10$ \\
Total with complete data: $\mathrm{n}=177$ & Lost-to-follow up: $\mathrm{n}=15(8 \%)$ \\
\hline
\end{tabular}

Interventions

1. Parent-Information (PI): information brochure to parents

2. Child-Program (CP): Delta DogSafe(TM) program (30-minute story telling and modelling with photographs and puppets)

3. Parent and Child Information/program (PICP): children in program + information brochure to parents

4. Control (C): no intervention

Outcomes

Questionnaires:

a) parents: dogs per household + parents' beliefs + child history + how parents thought their child would react with strange or familiar dog

b) child: answer by "Yes" or "No" to the question "would you pat this dog?" to a series of 10 photographs with a dog in a different scenario (high risk and low risk positions)

Measurements were conducted before the intervention and 4 weeks after the intervention with the same pictures.

Two indicators calculated: increased knowledge and increased caution

Notes $\quad$ Response rate of parental questionnaire: $112 / 192(58.33 \%)$

\section{Risk of bias}

\begin{tabular}{|c|c|c|}
\hline Item & Authors' judgement & Description \\
\hline Adequate sequence generation? & Unclear & $\begin{array}{l}\text { Quote: "The kindergarten classes participating in } \\
\text { the study were then randomly assigned to four lev- } \\
\text { els" } \\
\text { Comment: lack of information. }\end{array}$ \\
\hline Allocation concealment? & Unclear & No information provided. \\
\hline
\end{tabular}


Wilson 2003 (Continued)

\begin{tabular}{|c|c|c|}
\hline $\begin{array}{l}\text { Blinding? } \\
\text { Observed behaviour }\end{array}$ & Unclear & Not tested. \\
\hline $\begin{array}{l}\text { Blinding? } \\
\text { Knowledge }\end{array}$ & Unclear & No information provided. \\
\hline $\begin{array}{l}\text { Blinding? } \\
\text { Attitude }\end{array}$ & Unclear & No information provided. \\
\hline $\begin{array}{l}\text { Incomplete outcome data addressed? } \\
\text { All outcomes }\end{array}$ & Yes & $\begin{array}{l}\text { Quote:“... one kindergarten class in the control } \\
\text { group was lost to the study,... some children were } \\
\text { absent from class on one of the days data were col- } \\
\text { lected, and some failed to respond to all questions. } \\
\text { Data from these children were excluded from the } \\
\text { study...” } \\
\text { Comment: Numbers clearly stated. }\end{array}$ \\
\hline Free of selective reporting? & Yes & $\begin{array}{l}\text { All outcome measures mentioned in methods are } \\
\text { reported. }\end{array}$ \\
\hline Free of other bias? & Unclear & $\begin{array}{l}\text { Subgroup analysis between dog owners and non- } \\
\text { owners could have been useful }\end{array}$ \\
\hline
\end{tabular}

Characteristics of excluded studies [ordered by study ID]

\begin{tabular}{|c|c|}
\hline Study & Reason for exclusion \\
\hline Agan 2000 & $\begin{array}{l}\text { No evaluation of effectiveness. Description of an educational program (Fido! Friend or Foe) to prevent dog } \\
\text { bites. }\end{array}$ \\
\hline Avatkova 1979 & No evaluation of effectiveness. \\
\hline Bernardo 2001 & $\begin{array}{l}\text { Improper design to evaluate effectiveness. Insufficient information about control group } \\
\text { Compared characteristics of patients treated in an emergency department and living in the intervention area } \\
\text { to those not living in the intervention area, but no denominator available for the latest group. Intervention: } \\
\text { dissemination of 'Fido! Friend or Foe' colouring book to families of } 3 \text { high-risk geographic areas enrolled } \\
\text { with a primary care centre }\end{array}$ \\
\hline Butcher 2006 & No evaluation of effectiveness. Letter. \\
\hline Chevallier 1999 & No evaluation of effectiveness. \\
\hline Faulconbridge 2001 & $\begin{array}{l}\text { No report obtained. Comparative study possibly randomised. Intervention: distribution of a leaflet after a dog } \\
\text { bite injury. Outcome: longer-term adverse psychological effects in the children }\end{array}$ \\
\hline Gilchrist 2001 & Comment on Chapman 2000. \\
\hline
\end{tabular}


(Continued)

\begin{tabular}{ll}
\hline Kahn 2003 & No evaluation of effectiveness. \\
\hline Klaassen 1996 & CBA evaluating impact of change of legislation. \\
\hline Mills 2007 & Letter. \\
\hline Monti 1998 & $\begin{array}{l}\text { No evaluation of effectiveness. Description of an educational program to prevent dog bites (Don't worry, they } \\
\text { won't bite). }\end{array}$ \\
\hline Peak 2002 & No evaluation of effectiveness. \\
\hline Presutti 2001 & No evaluation of effectiveness. \\
\hline Riegger 1990 & No evaluation of effectiveness. \\
\hline Spiegel 2000 & $\begin{array}{l}\text { No control group. Evaluation of a 3-sessions educational program (BARK: Be Aware, Responsible, and } \\
\text { Kind) with a before-after design using questionnaires to measure change in knowledge and attitude }\end{array}$ \\
\hline Taylor 2007 & Letter. \\
\hline Whalen 2000 & No evaluation of effectiveness. \\
\hline
\end{tabular}

Characteristics of ongoing studies [ordered by study ID]

\section{De Keuster 2005}

\begin{tabular}{ll}
\hline Trial name or title & The Blue Dog. \\
\hline Methods & Before-after study. Control group? Randomisation? \\
\hline Participants & 3-year-old children. \\
\hline Interventions & Interactive CD in nursery schools (exposure) + training phase + parental reinforcement \\
\hline Outcomes & Score of correct answers immediately and after 2 weeks. \\
\hline Starting date & 2005 \\
\hline Contact information & $\begin{array}{l}\text { kmeints@lincoln.ac.uk } \\
\text { bluedog.admin@tiscali.co.uk } \\
\text { tiny.dekeuster@telenet.be }\end{array}$ \\
\hline Notes & \begin{tabular}{l} 
In contact with authors who are preparing a publication. \\
\hline
\end{tabular}
\end{tabular}


DATA AND ANALYSES

Comparison 1. Education vs no education

\begin{tabular}{|c|c|c|c|c|}
\hline Outcome or subgroup title & $\begin{array}{l}\text { No. of } \\
\text { studies }\end{array}$ & $\begin{array}{c}\text { No. of } \\
\text { participants }\end{array}$ & Statistical method & Effect size \\
\hline $\begin{array}{l}1 \text { Inappropriate behaviour } \\
\text { (observed) }\end{array}$ & 1 & & Odds Ratio (M-H, Random, 95\% CI) & Totals not selected \\
\hline 1.1 Crude data (no ICC) & 1 & & Odds Ratio (M-H, Random, 95\% CI) & Not estimable \\
\hline $\begin{array}{l}\text { 1.2 Provided or calculated } \\
\text { ICC }\end{array}$ & 1 & & Odds Ratio (M-H, Random, 95\% CI) & Not estimable \\
\hline 1.3 Estimated ICC=0.01 & 1 & & Odds Ratio (M-H, Random, 95\% CI) & Not estimable \\
\hline 1.4 Estimated ICC=0.2 & 1 & & Odds Ratio (M-H, Random, 95\% CI) & Not estimable \\
\hline
\end{tabular}

\section{Analysis I.I. Comparison I Education vs no education, Outcome I Inappropriate behaviour (observed).}

\begin{tabular}{|c|c|c|c|c|}
\hline \multicolumn{5}{|c|}{ Comparison: I Education vs no education } \\
\hline \multicolumn{5}{|c|}{ Outcome: I Inappropriate behaviour (observed) } \\
\hline Study or subgroup & $\begin{array}{r}\text { Experimental } \\
n / N\end{array}$ & $\begin{array}{r}\text { Control } \\
\mathrm{n} / \mathrm{N}\end{array}$ & $\begin{array}{r}\text { Odds Ratio } \\
\text { M- } \\
\text { H,Random,95\% } \\
\text { Cl }\end{array}$ & $\begin{array}{c}\text { Odds Ratio } \\
\text { M- } \\
\text { H,Random,95\% } \\
\text { Cl }\end{array}$ \\
\hline \multicolumn{5}{|c|}{ I Crude data (no ICC) } \\
\hline Chapman 2000 & $18 / 197$ & $118 / 149$ & $\rightarrow$ & $0.03[0.01,0.05]$ \\
\hline \multicolumn{5}{|c|}{2 Provided or calculated ICC } \\
\hline Chapman 2000 & $1 / 8$ & $5 / 6$ & $\longrightarrow$ & $0.03[0.00,0.57]$ \\
\hline \multicolumn{5}{|c|}{3 Estimated ICC $=0.01$} \\
\hline Chapman 2000 & $13 / 138$ & $83 / 105$ & $\rightarrow$ & $0.03[0.01,0.06]$ \\
\hline \multicolumn{5}{|l|}{4 Estimated ICC $=0.2$} \\
\hline Chapman 2000 & $2 / 21$ & $12 / 16$ & $\longrightarrow$ & $0.04[0.01,0.22]$ \\
\hline
\end{tabular}




\section{A P P E N D I C E S}

\section{Appendix I. Detailed search strategies}

Cochrane Injuries Group Specialised Register (searched 18 July 2008)

$\left(\operatorname{dog}^{*}\right)$ and (bite*) and (educat* or teach* or inform* or train* or instruct* or safe* or prevent* ${ }^{*}$ or securit*)

CENTRAL (The Cochrane Library Issue 3, 2008)

\#1 MeSH descriptor Dogs explode all trees

\#2 MeSH descriptor Bites and Stings explode all trees with qualifier: PC

\#3 bite* or bitten or attack*

\#4 (\#2 OR \#3)

\#5 \#1 AND \#4)

\#6 (dog* or canine*) and (bit* or attack*)

\#7 (\#5 OR \#6)

\#8 educat* or teach* ${ }^{*}$ or inform* ${ }^{*}$ or train* ${ }^{*}$ or instruct* or safe* $^{*}$ or prevent* or securit*

\#9 (\#7 AND \#8)

MEDLINE (to July 2008)

1. exp Dogs/

2. exp "Bites and Stings"/pc [Prevention \& Control]

3. (bite\$ or bitten or attack\$).ab,ti.

4. 1 and (2 or 3$)$

5. ((dog $\$$ or canine\$) adj5 (bit\$ or attack\$)).ab,ti.

6. 4 or 5

7. (educat $\$$ or teach $\$$ or inform $\$$ or train $\$$ or instruct $\$$ or safe $\$$ or prevent $\$$ or securit $\$$ ).ab,ti.

8. 6 and 7

EMBASE (1980 to July 2008)

1. $\exp \mathrm{DOG} /$

2. $\exp \mathrm{BITE} / \mathrm{pc}$ [Prevention]

3. $\exp$ Bite Wound/pc [Prevention]

4. (bite $\$$ or bitten or attack\$).ab,ti.

5.2 or 3 or 4

6. 1 and 5

7. exp Dog Bite/pc [Prevention]

8. $((\operatorname{dog} \$$ or canine $\$)$ adj5 (bit $\$$ or attack $\$))$.ab,ti.

9. 6 or 7 or 8

10. (educat $\$$ or teach $\$$ or inform $\$$ or train $\$$ or instruct $\$$ or safe $\$$ or prevent $\$$ or securit $\$$ ).ab,ti.

11.9 and 10

CINAHL (1980 to July 2008)

1. exp Dogs/

2. exp "Bites and Stings"/pc [Prevention \& Control]

3. (bite\$ or bitten or attack\$).ab,ti.

4. $S 1$ and $S 2$

5. $\mathrm{S} 1$ and $\mathrm{S} 3$

6. $\mathrm{S} 4$ or $\mathrm{S} 5$

7. educat* or teach* or inform* or train* $^{*}$ or instruct* or safe* $^{*}$ or prevent* or securit* $^{*}$

8. S6 and S7

LILACS (to July 2008)

$(\operatorname{dog} \$)$ and (bite\$) and (educat\$ or teach\$ or inform $\$$ or train $\$$ or instruct $\$$ or safe $\$$ or prevent $\$$ or securit $\$$ ) African Health Online (1966 to July 2008)

$\left(\operatorname{dog}^{*}\right)$ and (bite*) and (educat* or teach* or inform* or train* or instruct* or safe* or prevent* or securit*)

Current Controlled Trials Meta Register (searched July 18 2008)

$\left(\operatorname{dog}^{*}\right)$ and (bite*) and (educat* or teach* or inform* or train* or instruct* or safe* or prevent* or securit*)

PsycINFO (1970 to July (week 3) 2008)

Education of children and adolescents for the prevention of dog bite injuries (Review)

Copyright () 2009 The Cochrane Collaboration. Published by John Wiley \& Sons, Ltd. 
$\left(\operatorname{dog}^{*}\right)$ and (bite*) and (educat* or teach* or inform* or train* or instruct* or safe* or prevent* or securit*)

ERIC (to July 2008)

$\left(\operatorname{dog}^{*}\right)$ and $\left(\right.$ bite $\left.^{*}\right)$ and (educat* or teach* or inform* or train* or instruct* or safe* or prevent* or securit*)

ZETOC (searched 17 July 2008)

dog* bite* educat*

WOK: Science Citation Index, Social Science Citation Index (searched 18 July 2008)

Topic $=\left(\mathrm{dog}_{\mathrm{bit}}^{*}\right)$ AND Topic $=\left(\right.$ educat ${ }^{*}$ or teach* ${ }^{*}$ or inform* ${ }^{*}$ or train* ${ }^{*}$ or instruct ${ }^{*}$ or safe* ${ }^{*}$ or prevent ${ }^{*}$ or securit $\left.{ }^{*}\right)$ AND Topic $=\left(\right.$ child $^{*}$ or adolesc* or infant* or toddl* or bab* or paediat* or pediat*)

CAB Abstracts (searched 18 July 2008)

As MEDLINE strategy

\section{Appendix 2. Chapman 2000 - Acluster calculations}

16.07.2008 ACLUSTER-Design and Analysis of Cluster Randomization Trials Computation of Intra Class Correlation Coefficient - Binary Outcomes (Acluster 2000)

Parameters

From data file in C:\ACLUSTERIDATAICHAPMAN.DAT

With dictionary in C:IACLUSTERIDATAICHAPMAN.DCT

Aggregate file by cluster

Cluster identification in variable $\operatorname{IDCLUSTER}(1,1)$

Number of clusters identified 8

Mean No. of subjects per cluster 43

Outcome in variable $\operatorname{EVENT}(5,2)$

Number of records read 8 (346)

Number of subjects in variable SUBJECTS $(8,2)$

Between clusters mean square $\quad 6.1613$

Within clusters mean square .0984

Results

Intra correlation coefficient ICC $\quad .58915$

Inflation factor or design effect $\quad 25.89147$

Relative efficiency of cluster vs individually randomized design $\quad .03862$

16.07.2008 ACLUSTER-Design and Analysis of Cluster Randomization Trials

Binary Outcomes - Cluster-level Analysis, Comp. Randomised Design

Parameters

Aggregate file by cluster

From data file in C:IACLUSTERIDATAICHAPMAN.DAT

With dictionary in C:IACLUSTERIDATAICHAPMAN.DCT

No. of records read 8

Group identification in variable GROUP $(3,1)$

Number of groups identified 2

Groups considered in analysis 1, 2

Number of events in variable EVENT $(5,2)$

Cluster size in variable SUBJECTS $(8,2)$

Result

Education of children and adolescents for the prevention of dog bite injuries (Review)

Copyright () 2009 The Cochrane Collaboration. Published by John Wiley \& Sons, Ltd. 


\section{H I S T O R Y}

Protocol first published: Issue 2, 2004

Review first published: Issue 2, 2009

\begin{tabular}{l|l|l}
\hline Date & Event & Description \\
\hline 12 February 2009 & Amended & The title of the review has been changed. \\
\hline 9 May 2008 & Amended & Converted to new review format. \\
\hline
\end{tabular}

\section{CONTRIBUTIONS OFAUTHORS}

OD wrote the protocol, ran searches, selected trials, obtained papers, extracted data, contacted authors and wrote the review.

$\mathrm{KB}$ ran searches, selected trials, obtained papers and helped write the review.

MB wrote the protocol, ran searches, obtained papers and selected trials.

EJ selected trials and extracted data.

\section{DECLARATIONSOF INTEREST}

OD has contributed to the development of an educational leaflet for children on dog bite prevention (Truf' viens...) and has evaluated the feasibility and acceptability of introducing an educational programme on dog bite prevention in primary schools in Geneva.

None known for the other authors.

\section{SOURCES OF SUPPORT}

\section{Internal sources}

- Institut de Médecine Sociale et Préventive, 1211 GENEVE 4, Switzerland.

- Service de Santé de la Jeunesse, 1211 GENEVE 3, Switzerland.

- Cochrane Injuries Group - editorial base, UK.

\section{External sources}

- Cochrane Health Promotion and Public Health Field, Australia. 


\section{DIFFERENCES BETWEEN PROTOCOLANDREVIEW}

- added more databases to search

- used Cochrane Handbook (Higgins 2008) and RevMan 5 recommendations for assessing the risk of bias instead of Schulz 1995

- added risk of bias tables, a tool not available at the time the protocol was published

- use of Acluster software to calculate ICC and design effect

- sensitivity analysis with ICC of 0.01 and 0.2 instead of 0.1 and 0.2

\section{N D EX TERMS}

\section{Medical Subject Headings (MeSH)}

${ }^{*}$ Child Behavior; *Dogs; Adolescent; Behavior, Animal; Bites and Stings [* prevention \& control]; Randomized Controlled Trials as Topic

\section{MeSH check words}

Animals; Child; Child, Preschool; Humans 